Alex Etl

\title{
With the Image of Deterrence: Operation Atlantic Resolve
}

\begin{abstract}
As deterrence is to become a new pillar of Operation Atlantic Resolve and European Reassurance Initiative from 2017, the paper offers an analysis of these U.S. security programs through the lens of deterrence theory. Through the empirical analysis of $E R I$ and OAR, the author argues that these steps create only the false image of deterrence, while the very essence of the increased U.S. presence in Europe is still about assurance; nevertheless, this strategy would not be fully inefficient for two reasons. On the one hand, it helps to avoid the return of Cold War era uncertainty with its negative spirals and unintended consequences, while on the other hand it pushes European allies towards a more nuanced defence policy and does not disrupt the process of U.S. rebalancing either.
\end{abstract}

Keywords: NATO, United States of America, deterrence, Central Europe, reassurance

\section{Introduction}

As the Obama Administration announced, additionally to assurance measures, deterrence will become a new pillar of Operation Atlantic Resolve (OAR) and European Reassurance Initiative (ERI) from $2017 .{ }^{1}$ For this reason, the administration seeks to increase the budget of OAR and ERI significantly to 3.4 billion USD for FY 2017. This decision came into power after the RAND Corporation pointed out that according to the currently foreseeable scenarios in case of a hypothetical armed aggression, Russian forces could reach the outskirts of Tallinn and Riga within 60 hours, leaving NATO with a limited number of risky options, including an escalatory nuclear strike. ${ }^{2}$ Thus, ERI and OAR aim to increase U.S. non-nuclear deterrence capabilities in Europe in order to avoid a limited Russian attack on the Eastern Flank of NATO.

In terms of structure, the first section of the study starts with a short overview of the concept of deterrence, while the second, drawing on the theoretical pillars, introduces the most important aspects of OAR and ERI. Through the introduction to deterrence theory and the subsequent empirical analysis of ERI and OAR, this study concludes that these steps create only the false image of deterrence, while the very essence of the increased U.S. presence in Europe is still about assurance. Nevertheless, and in contrast with the RAND study, we do not argue that this strategy of the Obama Administration would be fully inefficient. On the one hand, it helps to avoid the return of Cold War era uncertainty

U.S. European Command: Operation Atlantic Resolve - Fact Sheet 2016, [online], 15.04.2016, p. 1. Source: Eucom.mil [28.06.2016.]

2 Shlapak, David A. - Johnson, Michael W.: Reinforcing Deterrence on NATO’s Eastern Flank, [online], 2016, p. 8. Source: Rand.org [06.01.2016.] 
with its negative spirals and unintended consequences, while on the other hand it pushes European allies towards a more nuanced defence policy and does not disrupt the process of U.S. rebalancing either.

\section{The concept of deterrence}

To demonstrate why the Obama Administration could only create a false image of deterrence, it is important to introduce the main conceptual pillars of the theory. In one of his most influential works, Robert Jervis argued that in some cases "to avoid disastrous situation, the state must display the ability and willingness to wage war." ${ }^{3}$ This is probably the most important element of the concept of deterrence. It emerges from uncertainty, since one actor can never be sure about the intentions of the other. As Herbert Butterfield points out, this element of uncertainty is what causes the tragic predicament in every human conflict - that even though both powers want to anxiously avoid war, their best intentions may fail as they cannot be sure about the goals of the other. ${ }^{4}$ And this provides them only a limited number of options - most importantly to increase their security through different measures - including deterrence.

As Brown and Arnold summarise the essence of deterrence: if an actor (A) perceives a threat of an attack from B, than A tries to alter B's plan by promising certain retaliation which leads to such damage to $B$ that it outweighs any potential gain from the original aggression. ${ }^{5}$ For a successful deterrence $\mathrm{B}$ has to receive, understand and believe A's measures while $\mathrm{B}$ also has to calculate the costs of his aggression. ${ }^{6}$ The main problem is that one can never be sure when deterrence works, only when it fails. ${ }^{7}$

For this reason, the concept of deterrence has to operate with a significant amount of uncertainty. Even if it is successful, the predicament again is that B cannot be sure whether these deterrence measures seek only to increase security or also to prepare for an attack. ${ }^{8}$ Thus it is possible that B introduces counter measures, which pushes A to increase his/her deterrence activity again. ${ }^{9}$ And even though both actors are perfectly peaceful, a negative spiral and an arms race emerge between them which make the stakes higher and higher. ${ }^{10}$ These unintended consequences became more and more relevant with the appearance of nuclear weapons but the basic logic of deterrence has still remained the same. It builds on the perception of fear through the promise of retaliation in order to avoid war.

This is obviously a narrow and incomplete introduction of the concept of deterrence, but this study does not aim to present the whole deterrence literature. My goal is rather to build on this short conceptual introduction and highlight that the Obama Administration used the word deterrence not in line with its theoretical foundations. This is relevant, since

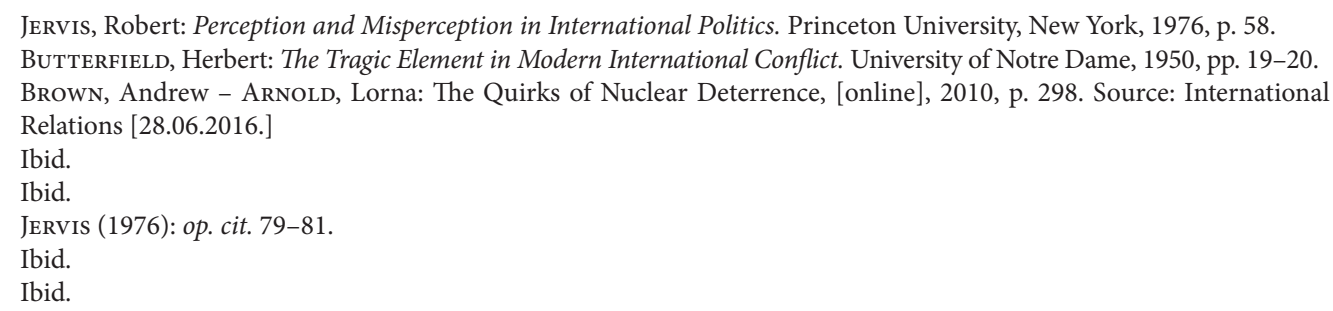


according to the administration's interpretation OAR, as well as ERI, will heavily build on deterrence measures from FY 2017.

The administration's decision can be seen as an answer for the analysis of the RAND Corporation which argued that the Russian forces could reach the outskirts of Tallinn and Riga within 60 hours in a limited attack, leaving NATO only with risky options, including an escalatory nuclear strike. ${ }^{11}$ Thus the main goal of OAR and ERI is to introduce nonnuclear deterrence measures, and for this reason I will examine non-nuclear deterrence only. The second part of the study will be an empirical analysis of the OAR and ERI measures, which can help us understand why the current non-nuclear deterrence measures are only imagined and do not provide real deterrence against a limited Russian attack.

\section{Operation Atlantic Resolve and the European Reassurance Initiative}

President Barack Obama initiated Operation Atlantic Resolve in April 2014 and European Reassurance Initiative during the summer of 2014. Operation Atlantic Resolve aimed to demonstrate the U.S. commitment to collective security and the commitment to the security of every ally, to augment air, ground and naval presence in the European region as well as to increase NATO readiness through Article 5 related trainings in order to deter Russia from regional hegemony. ${ }^{12}$ Additionally to OAR, European Reassurance Initiative was established separately as a 1-year-long emergency budget with 1 billion USD for FY 2015, to conduct multinational military exercises and trainings, to increase the responsiveness of U.S. NATO forces by pre-positioning of the equipment, to support non-NATO allies (especially Ukraine) as well as to increase the persistent U.S. presence in the continent. ${ }^{13}$ In 2015, the program was renewed with 789 million USD for FY 2016 and ERI came under the heading of OAR for 2016. ${ }^{14}$ Until this time, the main pillars of the operation did not change significantly, except that the support to Ukraine was no longer financed under the umbrella of OAR. ${ }^{15}$ However, FY 2017 can bring a significant change in the visibility as well as the impact of OAR and ERI since the proposed budget seeks to increase its funding to approximately 3.4 billion USD. ${ }^{16}$ According to the Obama Administration, this means that the operations will not only reassure European allies but also build on deterrence measures through the improvement of readiness and responsiveness. ${ }^{17}$ Meanwhile, the main geographic focus of OAR will remain Russia and Eastern Europe. ${ }^{18}$ Table 1 summarises the most important shifts in the budget allocations through the three years of OAR.

\footnotetext{
SHLAPAK-JOHNSON (2016): op. cit. 8.

U.S. European Command: Operation Atlantic Resolve (2014), [online] 29.01.2015. Source: Defense.gov [06.08.2016.] Ibid.

14 Cancian, Mark F. - Samp, Lisa Sawyer: The European Reassurance Initiative, [online], 09.02.2016. Source: Csis.org [06.08.2016.]

15 U.S. European Command: Operation Atlantic Resolve (2015), [online], 31.12.2015, p. 1. Source: Defense.gov [06.08.2016.]

16 U.S. European Command: Operation Atlantic Resolve - Fact Sheet 2016... 1.
}

17 Ibid.

18 Ibid. 
Table 1: European Reassurance Initiative - budget allocations

\begin{tabular}{|llll|}
\hline $\begin{array}{l}\text { European Reassurance Initiative (ERI) } \\
\text { (Dollars in Millions) }\end{array}$ & & & \\
& FY 2015 & FY 2016 & FY 2017 \\
Category & Enacted & Enacted & Request \\
Increased Presence & 423.1 & 471.4 & $1,049.8$ \\
Additional Bilateral and Multilateral Exercises & 40.6 & 108.4 & 163.1 \\
Enhanced Prepositioning & 136.1 & 57.8 & $1,903.9$ \\
Improved Infrastructure & 196.5 & 89.1 & 217.4 \\
Building Partnership Capacity & 13.7 & 62.6 & 85.5 \\
ERI Transfer Fund & 175.0 & - & - \\
Total: & 985.0 & 789.3 & $3,419.7$ \\
\hline
\end{tabular}

Source: Office of the Under Secretary of Defense (Comptroller): Department of Defense Budget,

Fiscal Year (FY) 2017, European Reassurance Initiative, [online], February 2016, pp. 16-17.

Source: comptroller.defense.gov [28.06.2016.]

As Table 1 summarises, ERI has five main pillars. These are increased presence, bilateral and multilateral exercises, enhanced prepositioning, improved infrastructure and building partnership capacity. While all of the components got larger funding for the FY 2017 request, more than $85 \%$ of the total budget is dedicated to two of them (increased presence and enhanced prepositioning). This means that the proposed deterrence measure in the framework of OAR should mostly build on these two elements. In the following, an analysis of the most important aspects of each pillar will follow.

\section{Increased presence}

After the end of the Cold War, the different administrations permanently decreased the U.S. military presence in Europe. Today the U.S. European Command can operate with approximately 62,000 personnel. ${ }^{19}$ This includes two brigade combat teams which are the Army's basic deployable manoeuvre units consisting of 4,000 to 5,000 troops. ${ }^{20}$ One of them is the $173^{\text {rd }}$ Airborne Brigade Combat Team in Italy, while the other one is the $2^{\text {nd }}$ Cavalry Regiment organised as a Stryker brigade combat team in Germany.

The ERI request for FY 2017 would increase their number with one more brigade combat team through continuous troop rotations of U.S. based armoured brigade combat teams. ${ }^{21}$ This would mean 9 months rotations from the U.S. to Europe from February $2017 . .^{22}$ In addition to this, the FY 2017 budget would also allocate a smaller portion of money to maintain the Navy and Marine presence in the Black sea region as well as to retain 20 F-15

19 Senate Committee on Armed Services: Statement of General Philip Breedlove Commander U.S. Forces Europe, 01.03.2016, p. 3.

20 CANCIAN-SAMP (2016): op. cit.

21 Operation Atlantic Resolve - Fact Sheet 2016... 1-2.

22 Ibid. 
aircraft in the $493^{\text {rd }}$ Fighter Squadron at Royal Air Force Base Lakenheath and to provide rotary wing aviation capability for the USEUCOM missions. ${ }^{23}$

\section{Bilateral and multilateral exercises}

The most visible aspects of OAR and ERI are the conducted bilateral and multilateral exercises in the territory of European member states. In the past few years U.S. forces conducted approximately 150 exercises/trainings/workshops with their European allies and partners. Most of these events were conducted by land forces and the Air Force, however, the Navy and Marine Forces participated in many cases as well.

Table 2: Conducted exercises according to their geographic spectrum

\begin{tabular}{|c|c|c|}
\hline 2014 & 2015 & $\begin{array}{c}2016 \\
\text { (before April 15) }\end{array}$ \\
\hline $1 \mathrm{x}$ Norway & $2 \times$ Hungary & $1 \times$ Norway \\
\hline $8 \times$ Romania & $9 \times$ Romania & $1 \times$ Romania \\
\hline $4 \times$ Bulgaria & $6 \times$ Bulgaria & $1 \mathrm{x}$ Iceland \\
\hline $6 \mathrm{x}$ Poland & $4 \times$ Poland & $3 \times$ Poland \\
\hline 6 x Germany & 6 x Germany & $1 \times$ Germany \\
\hline $1 \times$ Slovenia & $1 \times$ Croatia - Slovenia & 1 x Germany - Poland \\
\hline $9 \times$ Baltic region & $6 \times$ Baltic region & $1 \times$ Baltic region \\
\hline $1 \mathrm{x}$ France & $4 \mathrm{x}$ Baltic region - Poland & $1 \times$ Lithuania - Poland \\
\hline $1 \times$ United Kingdom & $1 \mathrm{x}$ United Kingdom & $1 \times$ Greece \\
\hline 1 x Czech Republic & $1 \mathrm{x}$ Svk $-\mathrm{Cz}-\mathrm{Hun}$ & $5 \times$ Black Sea \\
\hline $1 \times$ Iceland & $1 \mathrm{x}$ Rom - Hun - Est & \\
\hline $11 \times$ Black Sea & $9 \times$ Black Sea & \\
\hline $2 \times$ Baltic Sea & $3 \times$ Baltic Sea & \\
\hline $2 \times$ Serbia & $4 \times$ Mediterranean Sea & \\
\hline $1 \times$ Moldova & $1 \mathrm{x}$ "Western Europe" & \\
\hline $2 \times$ Ukraine & $2 \mathrm{x}$ "Eastern Flank" & \\
\hline $1 \times$ Georgia & $1 \mathrm{x}$ Netherlands - Bulgaria & \\
\hline \multirow[t]{3}{*}{$1 \times$ Bosnia and Herzegovina } & 1 x Ger - Bul - Itl - Rom & \\
\hline & $1 \mathrm{x}$ Ukraine & \\
\hline & $1 \times$ Georgia & \\
\hline
\end{tabular}

Source: Operation Atlantic Resolve (2014); Operation Atlantic Resolve (2015); Operation Atlantic Resolve - Fact Sheet 2016.

As Table 2 summarises, the main geographic focus of the conducted exercises was Central and Eastern Europe. More specifically, Romania, Bulgaria, Germany, Poland and the Baltic countries hosted most of these events. Table 2 also demonstrates that 2014 rather focused

23 Including an Armed Reconnaissance Squadron (AH-64), a General Support Aviation Battalion (CH-47 and air MEDEVAC), an Assault Battalion (UH-60s), and an Aviation Support Battalion. Source: Office of the Under Secretary of Defense (Comptroller): Department of Defense Budget, Fiscal Year (FY) 2017, European Reassurance Initiative, [online], February 2016. Source: comptroller.defense.gov [28.06.2016.] 
on static - one country - trainings, while the number of 'mobile' exercises with multiple places and host nations increased significantly for 2015. An interesting shift is that although the original plan of ERI clearly aimed to improve capacity building and interoperability in Georgia, Moldova and Ukraine, ${ }^{24}$ the 2015 and 2016 numbers show a decrease in this respect. ${ }^{25}$ This suggests that the Obama Administration does not want to risk a closer cooperation with the non-NATO allies in the framework of OAR since it could be interpreted as a provocation from the Russian side.

\section{Enhanced pre-positioning}

One of the key elements with the largest amount of increased ERI funding (1,904 million USD) for FY 2017 is the enhanced preposition of the military equipment in Europe. For this reason, these Army pre-positioned stocks would be the main pillars of OAR's deterrence measures. According to the plans of the administration, by the end of 2017 there will be one pre-positioned set of combat-ready equipment, which can support another Armoured Brigade Combat Team besides the three other stationing in the European theatre. ${ }^{26}$

As the ATP 3-35.1 doctrine emphasises, the Army pre-positioned stocks (APS) are essential elements of U.S. force projection, since they are significant enablers of the Army's rapid response. ${ }^{27}$ These pre-positioned elements are the third leg of the Strategic Mobility Triad besides airlift and sealift capabilities. ${ }^{28}$ Their primary task is to provide "immediate delivery of large amounts of equipment to meet short-notice crises". ${ }^{29}$ Thus APS can reduce the workload of airlift while it sustains the Soldier with all necessary equipment until the sea routes are established. ${ }^{30}$ On the other hand, the APS can be used as a deterrent capability through the form of training exercises. ${ }^{31}$ This is exactly, what we see in the framework of Operation Atlantic Resolve as well. However, this does not mean that APS cannot be used outside of its deployment region. As it happened during the preparation phase of Operation Iraqi Freedom in 2003, the Army can reposition equipment from any APS through strategic airlift or sealift. ${ }^{32}$ Thus they are not dedicated to specific units or theatres, but can be issued to units by the Secretary of Defense. ${ }^{33}$ The most important economic aspect of the whole project is that this APS structure does not need the permanent stationing of the staff and soldiers which can significantly reduce the costs of the deployment.

The Army pre-positioned stocks can be divided according to their characteristics. In this respect, the ATP 3-35.1 doctrine differentiates between five types of APS:

- Unit Sets contain equipment configured into unit sets and includes the unit basic load;

\footnotetext{
Operation Atlantic Resolve (2014)...

Operation Atlantic Resolve (2015); Operation Atlantic Resolve - Fact Sheet 2016...

Operation Atlantic Resolve - Fact Sheet 2016... 1-2.

ATP 3-35.1 Army Pre-Positioned Operations, [online], October 2015, pp. 1-2. Source: Armypubs.army.mil [06.01.2016.]

Ibid.

Ibid. 1.

Ibid. 1-3.

Ibid.

Ibid.

3 Ibid.
} 
- Operational Project Stocks, which "are materiel above normal table of organization and equipment, table of distribution and allowances, and common table of allowance authorizations tailored to key strategic capabilities";

- Army War Reserve Sustainment Stocks can provide "minimum essential support to combat operations and post-mobilization training beyond the capabilities of peacetime stocks, industry, and host nation support [...]. These stocks consist of major and secondary end items to sustain the operation by replacing combat losses and to replace supplies consumed in the operation";

- War Reserve Stocks for Allies which can be released to support allied forces. These stocks are also financed and owned by the United States;

- Activity Sets which are pre-positioned in order to support the deployment of the Army outside of the U.S. to conduct training and exercises. ${ }^{34}$

The announced APS in the framework of Operation Atlantic Resolve and European Reassurance Initiative will be a Unit Set equipment. ${ }^{35}$ Most importantly, it will provide a Division Headquarters, one Armoured Brigade Combat Team (ABCT), a Fires Brigade, a Sustainment Brigade and associated enablers. ${ }^{36}$ On the one hand the equipment will be sourced from existing depot stocks, while on the other hand ERI provides 1,096 million for additional procurements as well. ${ }^{37}$

Those pieces of equipment which will be sourced, are currently used by the rotationally deployed forces in Europe. This is the so-called European Activity Set or EAS. According to the plans, these "will remain in Europe, be repaired, upgraded, and converted into the core of the APS" ${ }^{38}$ In its current form the U.S. Army European Activity Set is "a combined-arms, battalion-sized group of vehicles and equipment" which is maintained at Grafenwoehr Training Area, Germany. ${ }^{39}$ Its creation was approved by the Army Chief of Staff in July 2012 in order to mitigate the loss of the two deactivated Brigade Combat Teams in Europe. ${ }^{40}$ The European Activity Set (EAS) cannot be used by allies or by any other country, it exclusively supports the U.S. Army ${ }^{41}$ According to the U.S. Army Fact Sheet, the $2^{\text {nd }}$ Battalion, $5^{\text {th }}$ Cavalry Regiment - a combined arms battalion of the $1^{\text {st }}$ Brigade Combat Team, $1^{\text {st }}$ Cavalry Division - is the unit currently designated for the use of EAS. ${ }^{42}$ However, this does not mean that the equipment or the vehicles cannot leave the Grafenwoehr Training Area. Some of the EAS sites are located on NATO's Eastern Flank, more specifically in Romania (Mihail Kogălniceanu Air Base), Bulgaria (Novo Selo Training Area) and

\footnotetext{
Ibid.

Office of the Under Secretary of Defense (Comptroller): Department of Defense Budget, Fiscal Year (FY) 2017, European Reassurance Initiative... 16-17.

36 Ibid.

37 Ibid.

38 Operation Atlantic Resolve - Fact Sheet 2016... 3.

39 U.S. Army European Activity Set, [online], 2016. Source: Eur.army.mil [06.01.2016.]

40 Daniel, Craig A. - Dothager, Robin T.: Resetting the theater to equip rotational forces in Europe, [online], 18.05.2016. Source: Army.mil [01.06.2016.]

${ }^{41}$ U.S. Army European Activity Set...

42 Ibid.
} 
Lithuania (Mumaičiai). ${ }^{43}$ According to the official data, the EAS consists of 12,000 pieces of equipment including 250 tanks and 1,750 support vehicles. ${ }^{44}$ Among these, there are M1A2 Abrams Main Battle Tanks; M2A3 Bradley Infantry Fighting Vehicles; A3 Bradley Support Team Vehicles; M109A6 Paladin Self-Propelled Howitzers; Mortar Carriers; Humvees and many other types. ${ }^{45}$ If the EAS is used outside of the Training Area, the equipment and vehicles can be transported by truck, rail, barge, ferry and aircraft. ${ }^{46}$ As RAND Corporation emphasises, there are 24 main battle tanks and 30 infantry fighting vehicles in the EAS. ${ }^{47}$ With additional procurements, these will provide the key equipment of the announced Army pre-positioned stock which will be able to support an Armoured Brigade Combat Team by the end of FY 2017. ${ }^{48}$

\section{Improved infrastructure and Partnership Capacity Building}

These two aspects of OAR and ERI mainly aim to support the first three pillars, which were introduced above. These include the improvement and modernisation of infrastructure elements as well as the construction of new facilities. Table 3 introduces the main projects under these headings, which are linked mostly to the development of airbases in Central and Eastern European countries.

Table 3: Main infrastructure developments within ERI

\begin{tabular}{|l|l|l|}
\hline \multicolumn{1}{|c|}{ Place } & \multicolumn{1}{c|}{ Project } & \multicolumn{1}{c|}{ Cost } \\
\hline Keflavik Airfield (Iceland) & Facilities Modification for P-8A & \$21.4 million \\
\hline Spangdahlem Airbase (Germany) & Infrastructure to support 5 ${ }^{\text {th }}$ generation fighter rotation ops & \$19.8 million \\
\hline Amari Airbase (Estonia) & Construct a bulk fuel storage capacity & \$6.5 million \\
\hline Graf Ignatievo Airbase (Bulgaria) & Construct funds Squadron Operations/Alert facility & \$3.8 million \\
\hline Graf Ignatievo Airbase (Bulgaria) & Extend a fighter ramp & \$7.0 million \\
\hline Câmpia Turzii Airbase (Romania) & Construct a Squadron Operations facility & \$3.4 million \\
\hline Câmpia Turzii Airbase (Romania) & Extend a parking apron & \$6.0 million \\
\hline Câmpia Turzii Airbase (Romania) & Construct a two-bay hangar & \$6.1 million \\
\hline Powidz Airbase (Poland) & Construct a Squadron Operations facility & \$4.1 million \\
\hline Łask Airbase (Poland) & Construct a Squadron Operations facility & \$4.1 million \\
\hline
\end{tabular}

Source: Office of the Under Secretary of Defense (Comptroller), Department of Defense Budget,

Fiscal Year (FY) 2017, European Reassurance Initiative, 19-23.

${ }^{43}$ European Activity Set - Fact Sheet, [online], 2016. Source: Eur.army.mil [28.06.2016.]

44 Behlin, Michael: European Activity Set turn-in officially underway in Lithuania, [online], 14.12.2015. Source: Army. mil [06.01.2016.]

45 U.S. Army European Activity Set Major Equipment, [online], Source: Eur.army.mil [06.01.2016.]

46 Daniel-Dothager (2016): op. cit.

47 SHLAPAK-Johnson (2016): op. cit. 8.

48 Office of the Under Secretary of Defense (Comptroller), Department of Defense Budget, Fiscal Year (FY) 2017, European Reassurance Initiative... 16-17. 
In addition to these, ERI also builds on the improvement of intelligence, surveillance and reconnaissance (ISR) capabilities. ${ }^{49}$ The other important aspect of partnership capacity building is the sustainment of the U.S.-Ukraine bi-lateral network (Maidan), to facilitate cyber security cooperation in the region. ${ }^{50}$

\section{Conclusions: No deterrence but still the better option}

As the conceptual introduction stated, the main point of deterrence is "that the state must display the ability and willingness to wage war"51 in order to avoid disastrous situations in some cases. The empirical analysis of the Operation Atlantic Resolve and European Reassurance Initiative shows that this willingness to wage war with Russia is missing from the whole concept. The introduced measures are clearly not in line with the propositions of the RAND Corporation, which suggested to deploy at least seven, combat-ready brigades, including three heavy armoured brigades - adequately supported by airpower, land-based fires and other enablers on the ground, in order to balance the Russian deployments and mitigate the threat of a limited attack. ${ }^{52}$ Thus, it seems unequivocal that ERI as well as OAR, in contrast with their official purpose, are not aimed to increase non-nuclear deterrence measures, because they are not able to do so in their current forms. Nevertheless, they are heavily building on the assurance of the European partners, but this is not equal to deterrence.

This is however not to say that this study agrees with the advices of the RAND Corporation to increase the U.S. presence in Europe. Even if RAND's conclusion were right, fulfilling their proposals would be not only extremely expensive ${ }^{53}$ for Washington but they would also fundamentally disrupt the long-term strategy of rebalancing. Instead, Washington and Europe have to face the truth that similarly to the case of terrorism, 100\% security does not exist. The international system always shows the risk of uncertainty. One can never be sure about the intentions of Vladimir Putin or his inner circle. Yes, there is a possibility that Russia will choose the option of a limited attack. Yes, OAR and ERI cannot promise adequate retaliation for a limited attack but without the permanent increase of U.S. forces in Europe this goal cannot be fulfilled. Even if Washington would decide to do so, there would sooner or later appear a new security risk which would leave Europe and the U.S. in a similarly difficult situation - and this is exactly how a negative spiral and an arms race could emerge.

\footnotetext{
Office of the Under Secretary of Defense (Comptroller), Department of Defense Budget, Fiscal Year (FY) 2017, European Reassurance Initiative... 16-17.

50 Ibid.

JERVIS (1976): op. cit. 58.

SHLAPAK-JOHNSON (2016): op. cit. 1.

53 According to RAND the total cost of buying three brand-new ABCT would be 13 billion USD. Additionally, their annual operating and support cost would be at least 2.7 billion USD, which however, does not include infrastructural and other expenses. Source: SHLAPAK-JoHnson (2016): op. cit. 11.
} 


\section{REFERENCES}

ATP 3-35.1 Army Pre-Positioned Operations, [online], October 2015. Source: Armypubs.army.mil [06.01.2016.] BeHLin, Michael: European Activity Set turn-in officially underway in Lithuania, [online], 14.12.2015. Source: Army.mil [06.01.2016.]

BRown, Andrew - ARnold, Lorna: The Quirks of Nuclear Deterrence, [online], 2010. Source: International Relations [28.06.2016.] DOI: https://doi.org/10.1177/0047117810377278

ButTerfield, Herbert: The Tragic Element in Modern International Conflict. University of Notre Dame, 1950. DOI: https://doi.org/10.1017/S0034670500044983

CANCIAN, Mark F. - SAMP, Lisa Sawyer: The European Reassurance Initiative, [online], 09.02.2016. Source: Csis.org [06.08.2016.]

Daniel, Craig A. - Dothager, Robin T.: Resetting the theater to equip rotational forces in Europe, [online], 18.05.2016. Source: Army.mil [01.06.2016.]

European Activity Set - Fact Sheet, [online], 2016. Source: Eur.army.mil [28.09.2016.]

JeRvis, Robert: Perception and Misperception in International Politics. Princeton University, New York, 1976. DOI: https://doi.org/10.2307/j.ctvc77bx3

Office of the Under Secretary of Defense (Comptroller): Department of Defense Budget, Fiscal Year (FY) 2017, European Reassurance Initiative, [online], February 2016. Source: comptroller.defense.gov [28.06.2016.]

Senate Committee on Armed Services: Statement of General Philip Breedlove Commander U.S. Forces Europe. 01.03.2016.

Shlapak, David A. - Johnson, Michael W.: Reinforcing Deterrence on NATO's Eastern Flank, [online], 2016. Source: Rand.org [06.01.2016.]

U.S. Army European Activity Set Major Equipment, [online], 2016. Source: Eur.army.mil [06.01.2016.]

U.S. Army European Activity Set, [online], 2016. Source: Eur.army.mil [06.01.2016.]

U.S. European Command: Operation Atlantic Resolve (2014), [online], 29.01.2015. Source: Defense.gov [06.08.2016.]

U.S. European Command: Operation Atlantic Resolve (2015), [online], 31.12.2015. Source: Defense.gov [06.08.2016.]

U.S. European Command: Operation Atlantic Resolve - Fact Sheet 2016, [online], 15.04.2016. Source: Eucom. mil [28.06.2016.] 